\title{
Oral Cream Dosage Form
}

National Cancer Institute

\section{Source}

National Cancer Institute. Oral Cream Dosage Form. NCI Thesaurus. Code C91166.

A cream intended for administration through the mouth. 